\title{
Copepod egg production in the western Mediterranean: response to food availability in oligotrophic environments
}

\author{
Enric Saiz*, Albert Calbet, Xabier Irigoien, Miquel Alcaraz \\ Dept. Biologia Marina i Oceanografia, Institut de Ciències del Mar, CSIC, Plaça del Mar s/n, 08039 Barcelona, \\ Catalonia, Spain
}

\begin{abstract}
Egg production rates of the copepods Centropages typicus, Clausocalanus lividus and Temora stylifera were determined in the temperate oligotrophic western Mediterranean during late spring and early summer. Egg production appeared to be severely limited and related to the concentration of $>5 \mu \mathrm{m}$ chlorophyll. Although phytoplankton can partially explain the observed gradient in egg production from coastal waters towards the open sea, it is not sufficient to explain the recorded egg production rates, and other non-pigmented items (microzooplankton) must be important components of the copepod diet. Copepod growth rates appeared uncoupled to the pattern in copepod abundance from coastal to oceanic waters, suggesting the role of other factors such as predation or advection in determining their distribution.
\end{abstract}

KEY WORDS: Zooplankton - Copepod · Egg production Growth · Centropages - Clausocalanus Temora. Mediterranean

\section{INTRODUCTION}

One of the main issues throughout the history of marine zooplankton ecology has been the determination of copepod production, the study of its variability and the attempt to ascertain which physical and biological factors have an influence on it. Laboratory studies have shown that food availability and temperature are 2 major factors controlling copepod productivity (e.g. Smith \& Lane 1985, Ban 1994). However, although in the oceans these variables must also control the growth and dynamics of copepod populations, natural environments are not as simple as most laboratory situations, and the relationships might not be straightforward. For instance, variables such as food availability can be difficult to quantify or even define in the field (Owen 1989, Jónasdóttir et al. 1995). Other factors, such as advection, predation and natural mortality (aging), can be crucial in understanding the fate of copepod populations in the oceans (Kimmerer \& McKinnon 1989, Ohman et al. 1996).

•E-mail:enric@icm.csic.es
Even though studies on copepod (egg) production are abundant in the literature, they are biased towards coastal environments and cold, temperate and high latitude seas, i.e. the North Atlantic (e.g. Tiselius et al. 1991, Plourde \& Runge 1993). There is a lack of studies on oligotrophic tropical and warm-temperate seas such as the Mediterranean, which are more likely representative of the major part of the open oceans in the world (Chisholm \& Roff 1990a, Calbet et al. 1996, Hopcroft \& Roff 1998 and references therein). This scarcity of information in such ecosystems denotes a significant limitation of the predictive power of current models for estimating copepod production (Huntley \& López 1992, Kiørboe \& Sabatini 1995, Hirst \& Sheader 1997, Hirst \& Lampitt 1998).

In this study we determined the abundance and growth rates of copepods during late spring-early summer in the Catalan Sea (western Mediterranean). We conducted the study along a coastal-open ocean transect where changes in biological and physical parameters would be expected to affect the dynamics of copepod populations. Besides the presence of a gradient in primary production from coastal waters to the open 
ocean (Estrada 1996) along the shelfbreak area of the Catalan Sea, there is a density front associated with the southwest flowing Ligurian-Provençal-Catalan current. Although for most of the year thermal stratification overrides the frontal signature at the surface, this area is characterized by high hydrodynamic activity at the mesoscale (Salat 1996).

Our aim was 2-fold: (1) to quantify copepod egg production rates in the Catalan Sea in order to address this lack of knowledge on the growth rates of copepods in oligotrophic seas; and (2) to determine how the egg production rates of copepods respond to a gradient in food availability from coastal to oceanic waters in order to ascertain which factors are mainly responsible for the driving of copepod production. Furthermore, some aspects related to the life strategies of the species studied are also discussed.

\section{MATERIAL AND METHODS}

Area surveyed. Sampling took place in the Catalan Sea on 2 consecutive cruises conducted in June 1995: VARIMED-95 (RV 'Hesperides', June 3 to 13, 1995). and FRONTS-95 (RV 'Garcia del Cid', June 18 to 23, 1995). Three transects perpendicular to the shoreline were visited (Fig. 1). Each transect was comprised of 3 stations: 1 station in shelf waters, a second on the shelfbreak at the margin of the Liguro-Provençal-Catalan current, and a third station in oceanic waters in a dome-like structure halfway between Barcelona and the Balearic Islands. In the VARIMED-95 cruise the sampling was restricted to the central transect. In FRONTS-95 sampling was conducted twice in the central transect, and once in the other transects. For data analysis, the 3 transects were pooled, and the stations in each corresponding area considered as replicates. This procedure resulted in 8 replicate visits to the shelf station, 7 to the shelfbreak, and 8 to the oceanic station.

Description of sampling. Temperature, salinity and in situ fluorescence were recorded with a Neil-Brown MARK-V CTD (VARIMED-95), and a Seabird-25 CTD (FRONTS-95), both equipped with a Sea Tech fluorometer. Water samples for the determination of chlorophyll concentration at chosen depths were filtered on $\mathrm{GF} / \mathrm{F}$ filters and $5 \mu \mathrm{m}$ membrane filters and kept frozen until analysis. Chlorophyll a was determined by fluorometry on acetone extracts. Depth-weighted average concentrations for the water column were computed using photic zone data only (from the surface to $60-70 \mathrm{~m}$ depth).

For the determination of mesozooplankton abundance, a double WP2 net $(56.5 \mathrm{~cm}$ mouth diameter, $200 \mu \mathrm{m}$ mesh size) was towed vertically at $30 \mathrm{~m} \mathrm{~min}^{-1}$

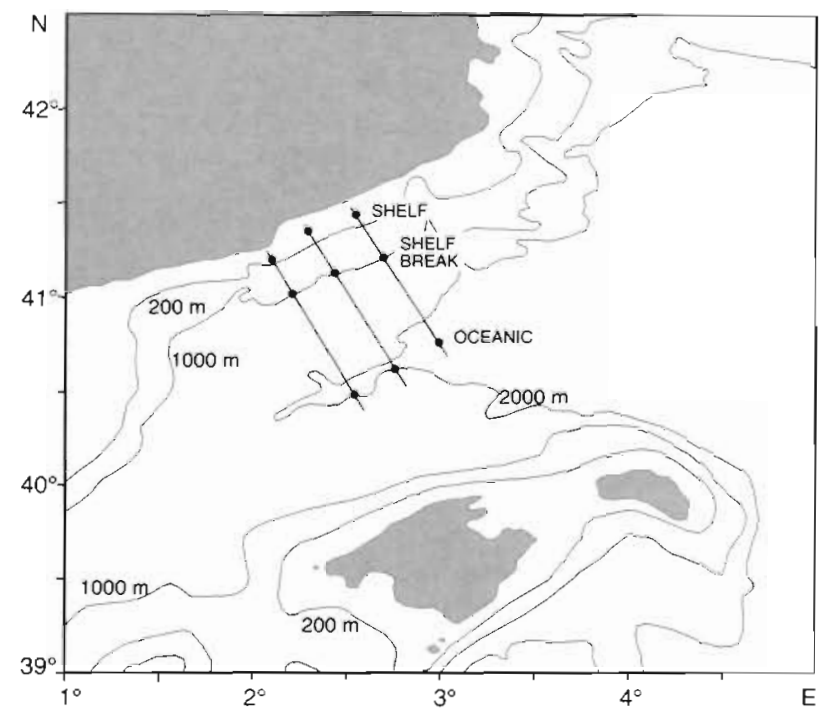

Fig. 1. Study area with position of the transects (lines) and statjons (filled dots) on cruises VARIMED-95 and FRONTS-95.

The shelf, shelfbreak and oceanic areas are also labeled

(20 $\mathrm{m} \mathrm{min}^{-1}$ in FRONTS-95) from $200 \mathrm{~m}$ depth to the surface (from the bottom to the surface when shallower). No corrections were made for filtering efficiency. For collecting live zooplankton, the nets were towed from $80 \mathrm{~m}$ depth (or near the bottom when shallower) to the surface at $10 \mathrm{~m} \mathrm{~min}^{-1}$. In this last case, the nets were fitted with 5 to $10 \mathrm{l}$ plastic bags as cod ends to prevent damage to organisms. Once on deck, the contents of the bags were poured into coolers and taken to the lab for sorting.

Egg production experiments. Egg production rates were determined for the free-spawning copepods Centropages typicus, Clausocalanus lividus and Temora stylifera. Paracalanus parvus was abundant, but most individuals had broken antennae due to sampling and this species was not used for the experiments. Egg-sac carrying species (e.g. Oithona spp. and some species of Clausocalanus) were also abundant, but we did not consider them because of methodological problems with the determination of field egg production rates in sac-spawning copepods (for instance, the difficulties in obtaining an in situ estimate of the time between successive clutches).

Copepods were sorted using a stereomicroscope, and groups of 4 (occasionally 3 or 5 ) adult females of each species were transferred to $625 \mathrm{ml}$ bottles previously filled with water from the fluorescence maximum (in situ water). This water had been screened through $53 \mu \mathrm{m}$ Nitex by reverse filtration in order to remove eggs and zooplankters. Usually 4 replicate bottles for species were prepared for each visit to the stations. On some occasions ( $26 \%$ of the visits), 5 or exceptionally 6 replicates were prepared. When adult females were 
very scarce, only 2 to 3 replicate bottles were prepared ( $26 \%$ of the visits). Control bottles with no added copepods were set up to take into account any eggs left after the screening. If any mortality was detected in a bottle, it was discarded, except when no eggs were laid, since in this case egg production rates for the remaining live individuals would not be biased.

The experimental bottles were kept on deck in an incubator with surface water running through. Temperature in the incubator oscillated between 18 and $20^{\circ} \mathrm{C}$ during the VARIMED-95 cruise and between 20 and $22^{\circ} \mathrm{C}$ during the FRONTS-95 cruise. The incubations were performed under the natural light cycle; however, light was dimmed by opaque plastic sheets. The bottles were gently stirred by being turned upside down several times during the incubations to prevent settling of algae. After ca $24 \mathrm{~h}$ the contents of the bottles were filtered onto $20 \mu \mathrm{m}$ sieves, the animals checked for activity and eggs and copepods preserved for counting and measuring later in the laboratory. When empty shells appeared because of egg cannibalism, they were also accounted for. Egg diameter was determined under an inverted microscope with the aid of a micrometer eyepiece. Cephalothorax length of the copepods was measured on video pictures, digitized with a frame grabber and analyzed with the software NIH Image.

Egg and female carbon contents were estimated from their size and length-weight relationships in the literature legg: carbon content $=0.139 \times$ volume 0.002, Huntley \& López 1992; Centropages typicus: carbon content $=0.06 \times \exp (4.612 \times$ length $)$, Davis \& Alatalo 1992; Clausocalanus spp.: $W=\exp [3.25 \times$ ln(length) - 19.65] and Temora turbinata: $W=\exp [3.34$ $x \ln$ (length) -19.59 ], where $W$ is $1.06 \times$ dry weight, Chisholm \& Roff 1990 b\}. Dry weight was converted into carbon content using a factor of 0.4 (Parsons et al. 1984)

Egg production rates were expressed as individual rates (eggs laid per female per day) and finite weightspecific fecundity $\left(G, \mathrm{~d}^{-1}\right)$. Average and maximum values between replicate bottles for each visit to the stations are shown. Instantaneous specific growth rates $\left(g . \mathrm{d}^{-1}\right)$ were computed as $g=\ln (G+1)$ (Chisholm \& Roff 1990a).

Occasionally, 2 additional experiments were conducted with natural populations of Centropages typicus. First, in order to investigate potential food limitation, the in situ water was enriched with a suspension of the autotrophic flagellate Rhodomonas baltica ( $7 \mathrm{ppm}$ by volume) prior to incubation. These incubations were run for $3 \mathrm{~d}$ and egg production was determined daily. A second experiment was conducted to determine the effect of temperature on egg production. Our aim was to determine the potential bias in our estimates of egg production rates as a result of conducting the incubations in surface water (ca $20^{\circ} \mathrm{C}$ ) instead of the range of temperatures which the copepods must experience through diel vertical migration. In the case of the western Mediterranean, a deep mesozooplankton maximum is located at the base of the pycnocline during daytime, in relation with the deep chlorophyll maximum; at night this zooplankton maximum is located in upper waters (Alcaraz 1985). For this experiment, 4 replicate bottles filled with enriched in situ water ( $R$. baltica, $7 \mathrm{ppm}$ ) and 4 individuals each were incubated for $2 \mathrm{~d}$ at 4 different temperatures: $13,16,20$ and $25^{\circ} \mathrm{C}$. The number of eggs laid was checked at 24 and $48 \mathrm{~h}$. During our study the temperature at the depth of the deep chlorophyll maximum was ca 13.5 to $14^{\circ} \mathrm{C}$.

\section{RESULTS}

A representative vertical density profile along the central transect is shown in Fig. 2. A conspicuous feature of the profile is the presence of a density front at the shelfbreak associated with the Catalan-LiguroProvençal current. This density front was masked by thermal stratification in surface waters.

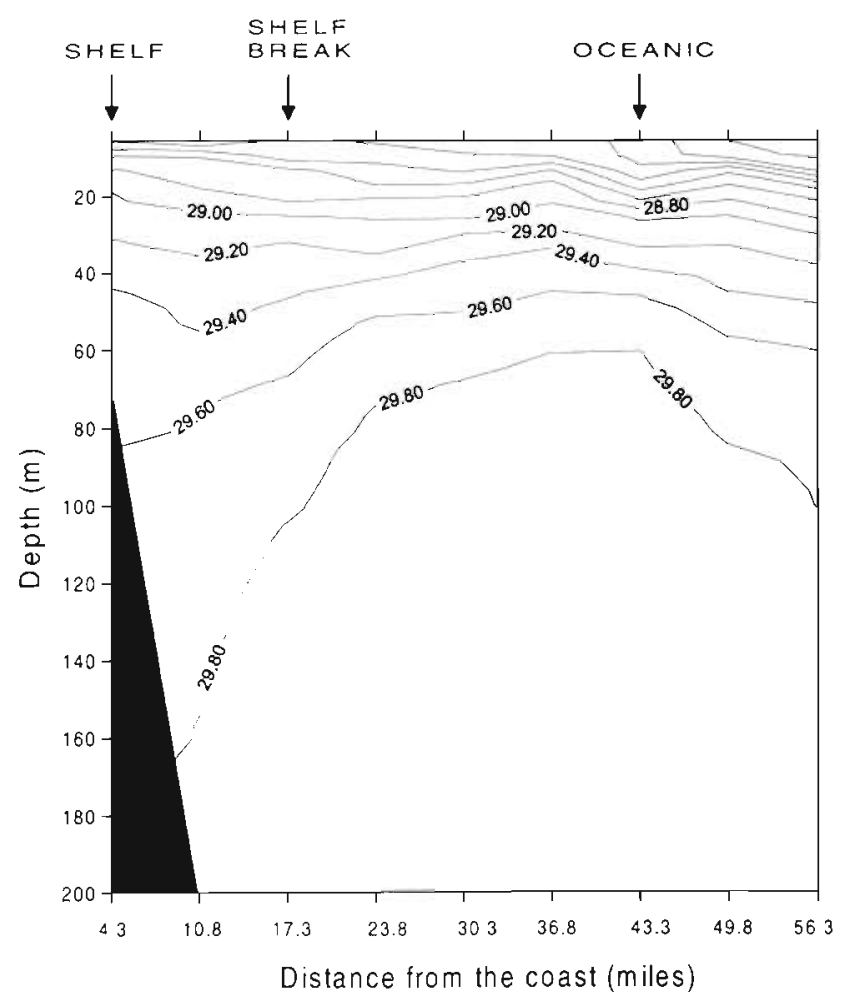

Fig. 2. Density distribution $\left(\sigma_{1}\right)$ along the central transect in VARIMED-95 cruise. The positions of the stations surveyed are indicated by arrows 
There was a linear relationship between total (GF/F) and $>5 \mu \mathrm{m}$ chlorophyll concentrations (Fig. 3a), which differed between shelf/shelfbreak waters and oceanic waters. Ocean water chlorophyll had a much lower contribution of $>5 \mu \mathrm{m}$ particles $\left(\mathrm{ANCOVA}_{\text {; }}\right.$ slopes significantly different, $\mathrm{p}<0.001$; intercepts not different, $p>0.1$ ). As a consequence and in spite of the fact that total chlorophyll concentration tended to increase offshore, the concentration of $>5 \mu \mathrm{m}$ chlorophyll was significantly higher at the shelf and shelfbreak stations than at the oceanic station (Fig. 3b).

Mesozooplankton and copepod abundance (Fig. 4) did not differ among shelf, shelfbreak and open sea waters, and were independent of daytime (2-way ANOVA tests for the mesozooplankton and the copepod integrated abundances; the factors were daytime, stations and their interaction; in all cases $p>0.1$, even when the tests were conducted without an outlier value for the shelfbreak stations). However, copepods represented 59 and $66 \%$ of mesozooplankton at the shelf and shelfbreak waters respectively, while at the oceanic station they made up to $78 \%$ of the individuals (Table 1).

Centropages typicus, Paracalanus parvus and Clausocalanus spp. were the dominant copepods in mesozooplankton, followed by Oithona spp. and Temora stylifera (Table 1). No conspicuous differences were evident between the 3 groups of stations regarding the composition of the copepod community. Body and egg sizes of the copepod species used for egg production are presented in Table 2.

Fig. 5 shows the average and maximum egg production rates of Centropages typicus, Clausocalanus lividus and Temora stylifera. Average and maximum egg production rates of $C$. typicus and $C$. lividus did

Table 1 Composition of the mesozooplankton and copepod communities at the shelf, shelfbreak and oceanic stations. Relative abundance of different zooplankton groups expressed as percentage ( \pm standard error, SE) of (a) total mesozooplankton, (b) total copepods

\begin{tabular}{|c|c|c|c|}
\hline & Shelf & Shelfbreak & Oceanic \\
\hline \multicolumn{4}{|c|}{ (a) $\%$ of total mesozooplankton } \\
\hline Copepods & $59 \pm 2.5$ & $66 \pm 2.1$ & $78 \pm 2.2$ \\
\hline Appendicularians & $16 \pm 2.4$ & $13 \pm 1.5$ & $8 \pm 0.8$ \\
\hline Cladocerans & $9 \pm 2.7$ & $6 \pm 1.6$ & $3 \pm 0.5$ \\
\hline Doliolids and salps & $2 \pm 0.7$ & $2 \pm 0.7$ & $4 \pm 1.1$ \\
\hline Others & $14 \pm 1.1$ & $13 \pm 1.8$ & $7 \pm 0.8$ \\
\hline \multicolumn{4}{|l|}{ (b) $\%$ of total copepods } \\
\hline $\begin{array}{l}\text { Paracalanus }+ \\
\text { Clausocalanus }\end{array}$ & $41 \pm 4.0$ & $40 \pm 3.8$ & $54 \pm 2.2$ \\
\hline Centropages typicus & $28 \pm 3.2$ & $19 \pm 2.6$ & $19 \pm 1.2$ \\
\hline Oithona sp. & $11 \pm 1.1$ & $14 \pm 1.9$ & $10 \pm 1.4$ \\
\hline Temora stylifera & $4 \pm 1.2$ & $2 \pm 0.6$ & $1 \pm 0.3$ \\
\hline Acartia & $1 \pm 0.4$ & $1 \pm 0.2$ & $1 \pm 0.3$ \\
\hline
\end{tabular}
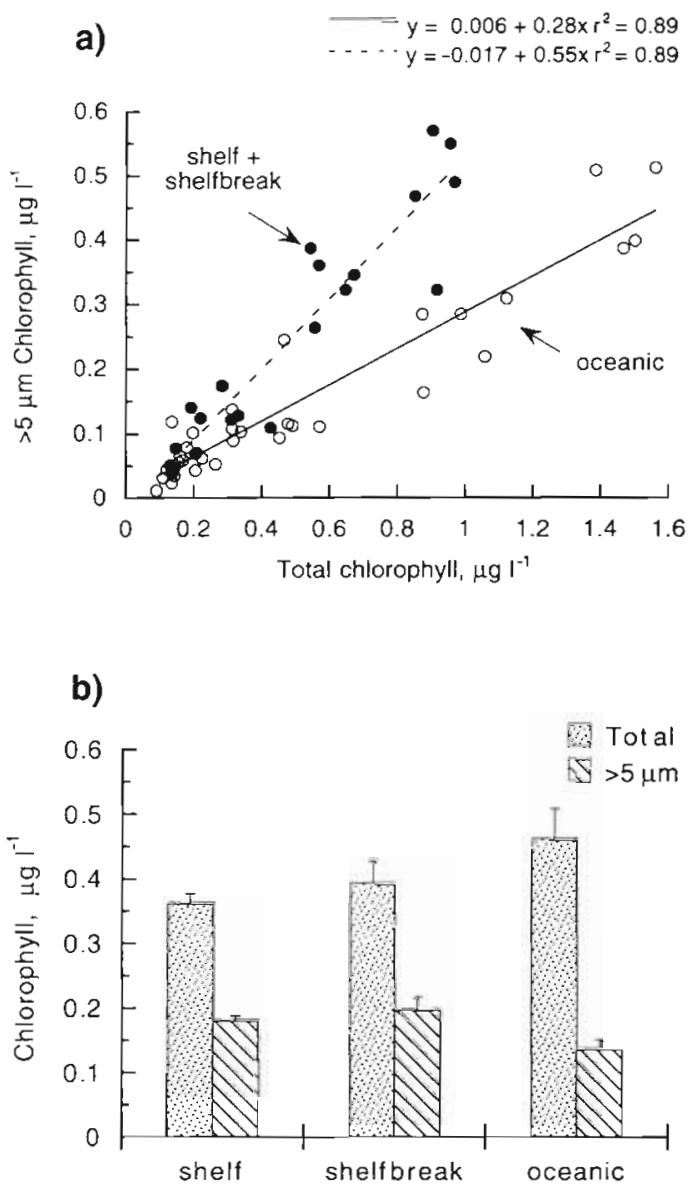

Fig. 3. (a) Scatterplot of total (GF/F) chlorophyll concentration versus the $>5 \mu \mathrm{m}$ fraction. ( $\bullet$ Shelf and shelfbreak stations; (o) oceanic stations. (b) Total chlorophyll and $>5 \mu \mathrm{m}$ chlorophyll concentration (mean $\pm \mathrm{SE}_{i} \mu \mathrm{g} \mathrm{l}^{-1}$ ) at the shelf, shelfbreak and oceanic stations throughout the period studied

not differ between shelf and shelfbreak waters $(C$. typicus: Tukey-Kramer HSD test, $\mathrm{p}>0.05$ for both average and maximum rates; $C$. lividus: Welch ANOVA for unequal variances, $\mathrm{p}>0.1$ for average rates, Tukey-Kramer HSD test, $p>0.05$ for maximum rates), and both differed from the oceanic ones, which were lower (C. typicus: 1-way ANOVA, $p<0.02$ and $p<0.007$ for average and maximum rates respectively; C. lividus: Welch ANOVA for unequal variances, $p<0.03$ for average rates, 1 -way ANOVA, $p<0.032$ for maximum rates). T. stylifera did not show differences in egg production rates between stations ( $\mathrm{p}>0.1)$. Specific instantaneous egg production rates showed the same pattern as the per individual rates (Table 3).

No clear trends appeared between total chlorophyll concentration and average egg production rates in the different visits to each area (Fig. 6, linear regression analysis, $p>0.05$ for each species). A significant tendency towards higher egg production rates at higher concentrations of $>5 \mu \mathrm{m}$ chlorophyll (which corre- 

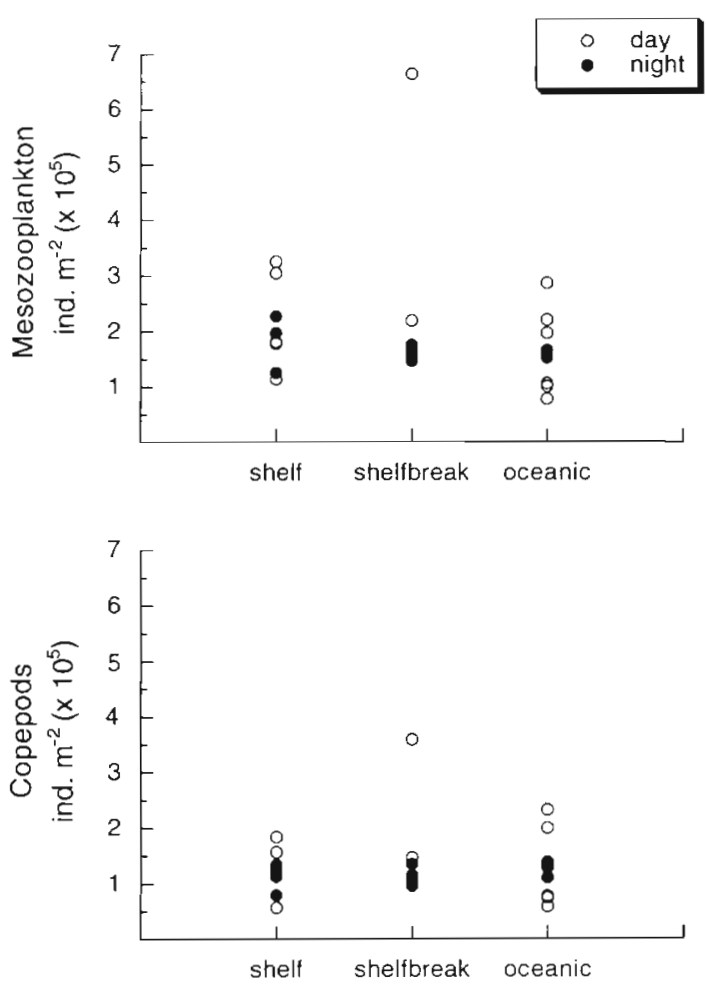

Fig. 4. Mesozooplankton and copepod abundance (ind. $\mathrm{m}^{-2}$ ) in the sampled area. Vertical net tows integrated 0 to $200 \mathrm{~m}$ for shelfbreak and oceanic stations, and 0 to 60 or 0 to $75 \mathrm{~m}$ for shelf stations

spond to incubations conducted at the shelf and shelfbreak stations) appeared for Centropages typicus (only after weighing the average egg production rates with the inverse of their standard error; $\mathrm{r}^{2}=0.25, \mathrm{p}<0.04$ ). Clausocalanus lividus also showed the highest average egg production rates at high $>5 \mu \mathrm{m}$ chlorophyll concentrations, but the relationship was not significant. Scatterplots of maximum egg production rates showed a similar pattern to the average ones, with no signifi-

Table 2. Copepod cephalothorax length ( $\mu \mathrm{m}, \pm \mathrm{SE}$ ) and egg diameter $(\mu \mathrm{m}, \pm \mathrm{SE})$ for the species studied

\begin{tabular}{|llcc|}
\hline Species & Station & Metasome & Egg \\
\hline Centropages typicus & $\begin{array}{l}\text { Shelf } \\
\text { Shelfbreak }\end{array}$ & $987 \pm 10.7$ & $74.9 \pm 0.70$ \\
& Oceanic & $917 \pm 11.5$ & $72.1 \pm 0.76$ \\
& & & \\
Clausocalanus lividus & Shelf & $1129 \pm 10.1$ & $70.5 \pm 0.81$ \\
& Shelfbreak & $1125 \pm 16.4$ & $67.3 \pm 1.11$ \\
& Oceanic & $1080 \pm 6.9$ & $67.3 \pm 1.49$ \\
Temora stylifera & Shelf & $977 \pm 8.6$ & $74.3 \pm 0.55$ \\
& Shelfbreak & $1011 \pm 3.0$ & $73.4 \pm 0.60$ \\
& Oceanic & $977 \pm 10.6$ & $73.4 \pm 0.66$ \\
\hline
\end{tabular}
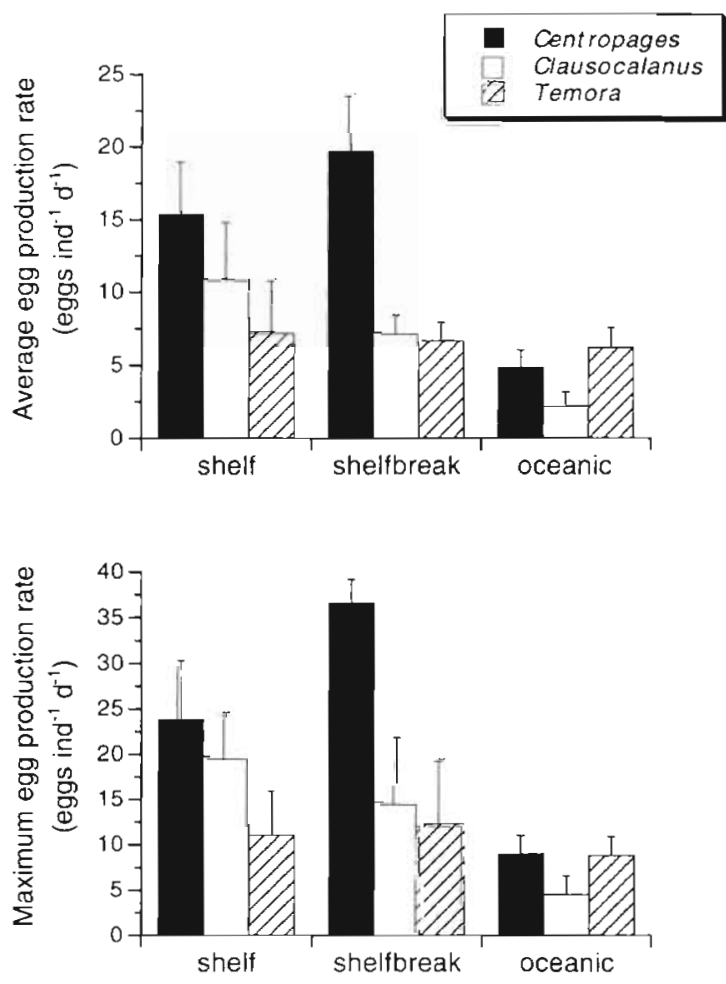

Fig. 5. Centropages typicus, Clausocalanus lividus and Temora stylifera. Average and maximum egg production rates of copepods at the shelf, shelfbreak and oceanic stations. Ensemble values (mean $\pm \mathrm{SE}$ ) between stations are shown

cant relationship between maximum egg production rates and $>5 \mu \mathrm{m}$ chlorophyll concentration (linear regression analysis, $\mathrm{p}>0.1$ ).

At the end of the study period (FRONTS-95 cruise) we observed a remarkable mortality of Centropages typicus during the incubations $(30 \%$, while it was $3 \%$ in the VARIMED-95 cruise), occasionally affecting all the individuals in the bottle. The surviving individuals frequently appeared slow moving and generally in poor shape. This fact was quite unexpected because through the previous experiments mortality had been negligible. This mortality appeared to be natural and not due to handling. Concurrent incubations with Temora stylifera and Clausocalanus lividus succeeded with no mortality. We also kept juvenile $C$. typicus in the same conditions with no mortality observed.

It is worth mentioning that these females, despite dying or being in poor condition (barely swinming), continued laying eggs at rates of up to 28 eggs female ${ }^{-1}$ $\mathrm{d}^{-1}$ in bottles where all females had died at the end of the $24 \mathrm{~h}$ incubation. Egg production rates of Centropages typicus based on bottles with mortality did not differ significantly from egg production rates computed from bottles with live animals only, i.e. the usual procedure (Fig. 7, 2-way ANOVA, p >0.1). 
Table 4 shows the response of egg production to the enrichment with Rhodomonas baltica. The increase in egg production rate due to enrichment (expressed as $\%$, based on the average egg production integrated for $3 \mathrm{~d}$ ) tended to be highest for the populations of Centropages typicus at the oceanic stations. The time lag to achieve the highest increase in egg production rates seemed to be longer (ca 2 d) for the aceanic C. typicus.

The effect of temperature and acclimation time on egg production rates is shown in Fig. 8. During the first day of incubation the highest egg production rates were achieved at $16^{\circ} \mathrm{C}$, although differences from egg production rates at 13 and $20^{\circ} \mathrm{C}$ were not significant (1-way ANOVA test, $\mathrm{p}>0.1$ ). On the second day (i.e. after 24 h acclimation), the highest egg production rates for Centropages typicus were achieved at $20^{\circ} \mathrm{C}$. Temperatures of $25^{\circ} \mathrm{C}$ had a negative effect on egg production. The $Q_{10}$ value for egg production between 13 and $20^{\circ} \mathrm{C}$, computed for the data of the second day, was 4.1. We concluded from this experiment that although the copepods may experience a range of temperatures through their diel vertical migration from ca $13.5-14^{\circ} \mathrm{C}$ (when they are close to the deep chlorophyll maximum during the day) to warmer surface waters at night, the procedure of conducting the incubations for $24 \mathrm{~h}$ in surface waters (ca $20^{\circ} \mathrm{C}$ ) did not affect the estimated copepod egg production rates. Changes in incubation temperature seemed to require a longer period (at least $2 \mathrm{~d}$ ) to be reflected in egg production rates.

\section{DISCUSSION}

One of the goals of this work was to increase knowledge of the instantaneous growth rates of copepods in oligotrophic and warm seas and put them in a context with previous work in other areas. In this sense, although egg production has been used in the literature as an estimator of copepod growth rate under the assumption of similarity between juvenile and adult growth rates (Sekiguchi et al. 1980, Berggreen et al. 1988), there is evidence that this may not be true in the field (Peterson et al. 1991, Hirst \& Lampitt 1998, Hopcroft \& Roff 1998). This lack of similarity can be a consequence of: (1) size-dependent differences in food availability, and (2) the fact that ensemble egg production rates based on the incubation of groups of females might also include adult females which are not fertile (Hay 1995, Ohman et al. 1996). Thus, maximum egg
Table 4. Centropages typicus. Comparison of average egg production rates (eggs ind ${ }^{-1} \mathrm{~d}^{-1}, \pm \mathrm{SE}$ ) from incubations in natural (in situ) and enriched water. Also shown is the percentage of increase in egg production due to enrichment. A total of 8 experiments were conducted: 3 in shelf waters, 2 at the shelfbreak and 3 at the oceanic stations

\begin{tabular}{|lrrrrrr|}
\hline Station & In situ & \multicolumn{2}{c}{ Enriched } & \multicolumn{2}{c}{ Enriched } & \multicolumn{2}{c|}{ Enriched } \\
& & Day 1 & Day 2 & Day 3 & incr. \\
\hline Shelf & $7 \pm 3.7$ & $32 \pm 9.0$ & $31 \pm 6.4$ & $19 \pm 2.8$ & 273 \\
& $33 \pm 5.7$ & $67 \pm 6.4$ & $61 \pm 5.6$ & $26 \pm 4.5$ & 54 \\
& $24 \pm 7.6$ & $32 \pm 8.0$ & $34 \pm 11.1$ & $39 \pm 7.5$ & 43 \\
Shelfbreak & $22 \pm 5.2$ & $43 \pm 8.1$ & $16 \pm 3.8$ & $28 \pm 8.8$ & 35 \\
& $22 \pm 9.6$ & $28 \pm 4.3$ & $47 \pm 4.3$ & $35 \pm 9.3$ & 64 \\
Oceanic & $8 \pm 1.2$ & $7 \pm 5.0$ & $19 \pm 6.2$ & $25 \pm 3.7$ & 112 \\
& $8 \pm 2.7$ & $14 \pm 3.8$ & $38 \pm 6.8$ & $22 \pm 2.9$ & 192 \\
& $3 \pm 0.9$ & $17 \pm 0.3$ & $36 \pm 12.1$ & $29 \pm 6.7$ & 897 \\
\hline
\end{tabular}

Table 5. Clearance rates on $>5 \mu \mathrm{m}$ pigmented food items $(\mathrm{ml}$ swept clear ind.$^{-1} \mathrm{~d}^{-1}$ ) required to sustain the maximum egg production rates found during the study

\begin{tabular}{|llcc|}
\hline Species & Station & C:chl 40 & C:chl 10 \\
\hline Centropages typicus & Shelf & 242 & 969 \\
& Shelfbreak & 340 & 1361 \\
& Oceanic & 123 & 490 \\
Clausocalanus Iividus & Shelf & 166 & 664 \\
& Shelfbreak & 107 & 430 \\
& Oceanic & 72 & 289 \\
Temora stylifera & Shelf & 98 & 392 \\
& Shelfbreak & 106 & 425 \\
& Oceanic & 131 & 526 \\
\hline
\end{tabular}


production rates are probably more related to juvenile growth. Our estimated maximum egg production rates were 42 to $104 \%$ higher than the average ones. These maximum egg production rates are not actual maximum rates of single individuals, but maximum rates between replicated bottles for each station; they are 'per bottle data' based on several copepods incubated in the bottle. Nevertheless, they should be closer to juvenile growth rates than the standard average egg production rates are and very likely less subject to bias than maximum rates estimated on single individuals.

An initial comparison indicates that the range of egg production rates found in our study are within the values reported in the literature for these or related species (Centropages typicus: 23 to 76 eggs ind.-1 $\mathrm{d}^{-1}$, Smith \& Lane 1987; ca 5 to 100 eggs ind.$^{-1} \mathrm{~d}^{-1}$ all year round, Ianora \& Buttino 1990; only occasional data have been found for Temora stylifera in the literature but for T. longicornis: 2 to 54 eggs ind.$^{-1} \mathrm{~d}^{-1}$, Peterson \&

\section{Centropages typicus}

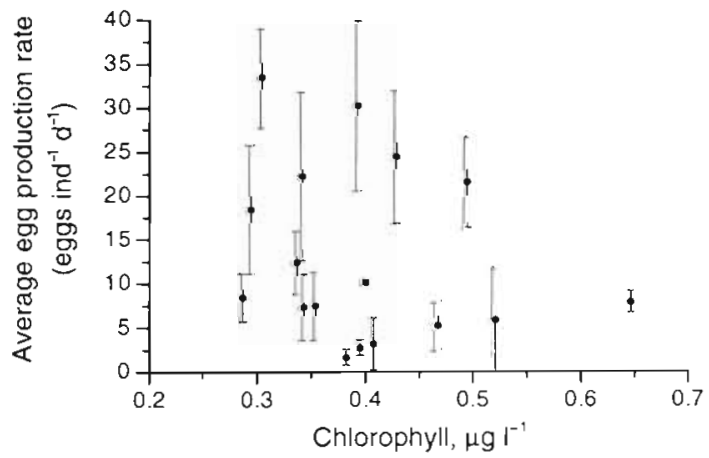

Clausocalanus lividus

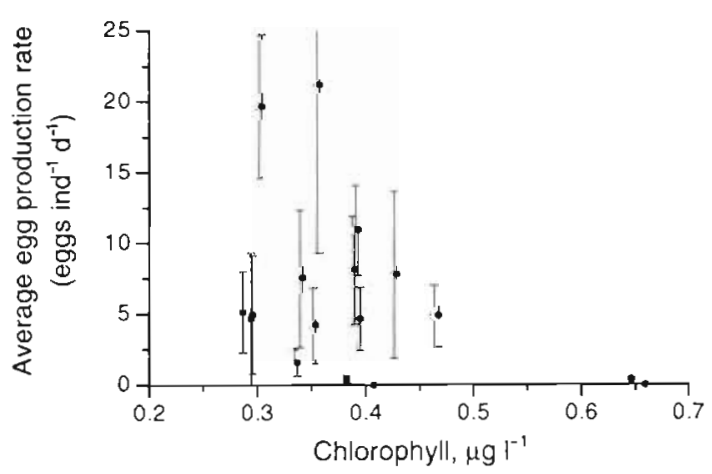

Temora stylifera

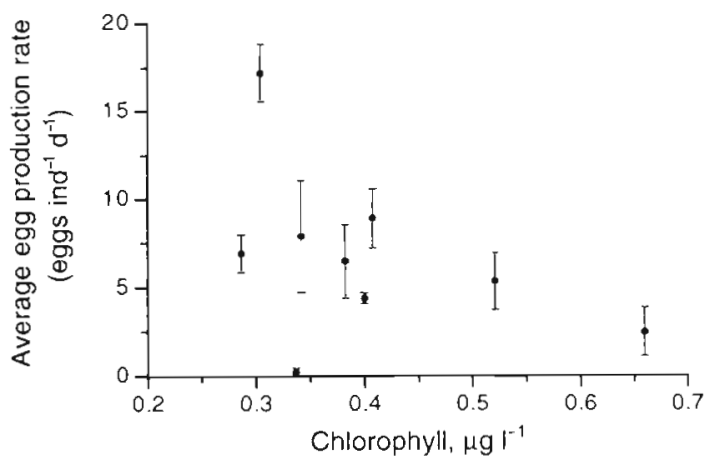

\section{Centropages typicus}

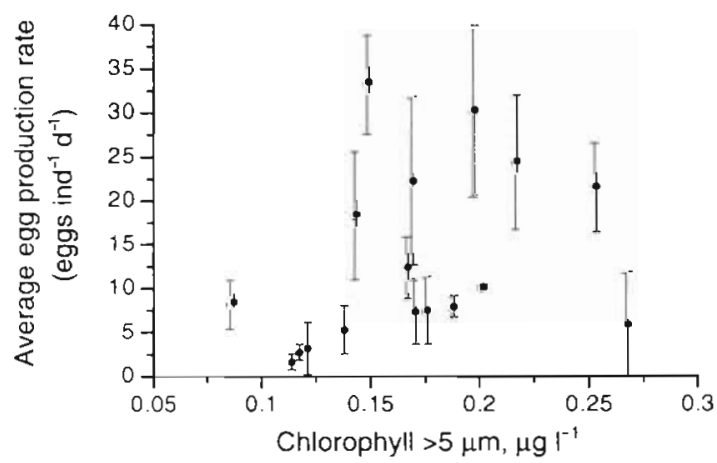

Clausocalanus lividus

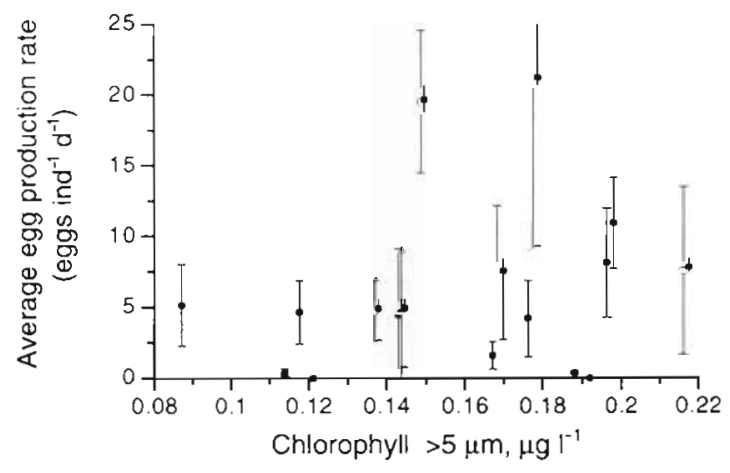

Temora stylifera

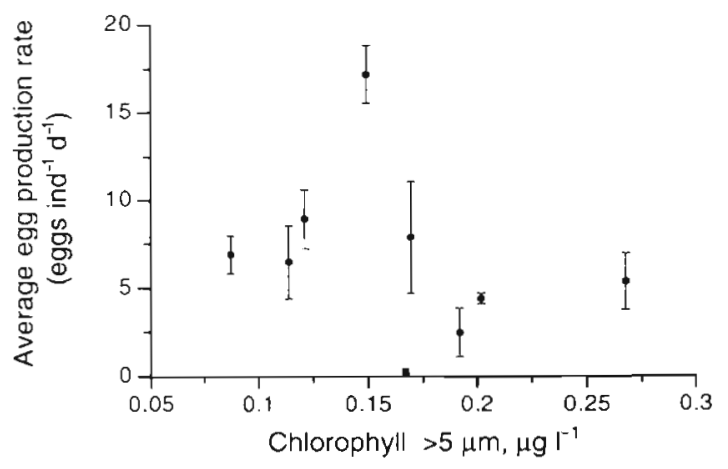

Fig. 6. Centropages typicus, Clausocalanus lividus and Temora stylifera. Scatterplots of average egg production rate, and total and $>5 \mu \mathrm{m}$ chlorophyll concentrations. Bars are standard errors computed between replicate bottles for each visit to the stations 


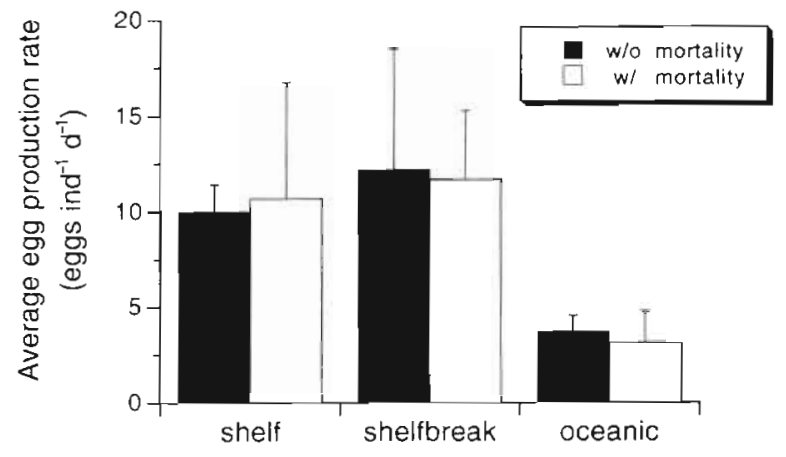

Fig. 7 Centropages typicus. Average egg production rates $( \pm$ SE) on cruise FRONTS-95. Data for incubation bottles without mortality are compared to data for bottles with mortality. (Note: the data for bottles with mortality were not used in the previous and further analyses)

Kimmerer 1994; up to ca 50 eggs ind. ${ }^{-1} \mathrm{~d}^{-1}$, Kiørboe \& Nielsen 1994). The egg production rates presented here for Clausocalanus lividus are, to our knowledge, the first for this species. The reports on egg production rates for the genus Clausocalanus by Sazhina (1985) and Webber \& Roff (1995) are for sac-bearing species of this genus (see Saiz \& Calbet 1999).

A proper comparison of the copepod growth rates obtained in this study with data from other areas is not easy because it depends on temperature, food availability, body size and species specificity. We have attempted this comparison by applying recent global models for predicting growth rates of broadcastspawning copepods in the oceans (Kiørboe \& Sabatini 1995, Hirst \& Lampitt 1998). The model of Kiørboe \& Sabatini (1995) is based on the results of a literature search for egg production rates in the laboratory under

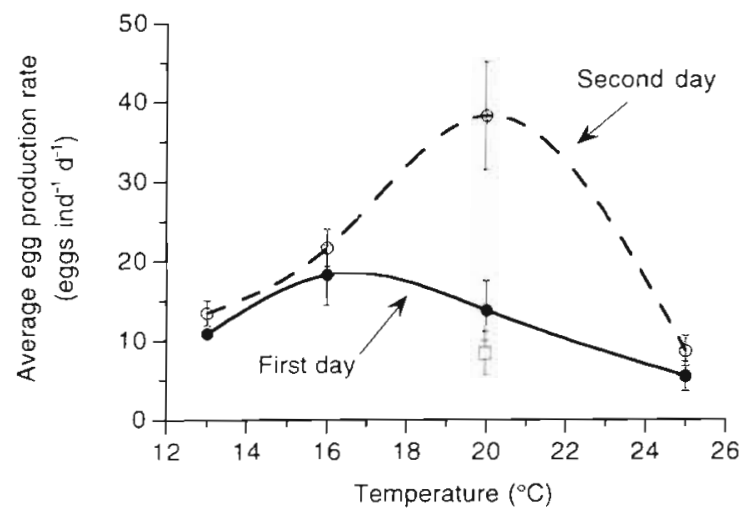

Fig. 8. Centropages typicus. Average egg production rates $( \pm S E)$ as a function of the incubation temperature in saturating food conditions (enriched water). $(\bullet)$ First day incubation; () second day incubation. The average egg production rate ( $\pm \mathrm{SE}$ ) of copepods incubated in natural, non-enriched water (in situ) is also included for comparison $\left(=; 20^{\circ} \mathrm{C}\right)$ saturating food conditions. It predicts maximum expected adult growth rates as a function of body size, and explains $30 \%$ of the variance of the data. The models of Hirst \& Lampitt (1998) provide expected growth rates of juvenile and adult copepods in a variety of natural habitats as a function of body weight and temperature. Respectively, 54 and $43 \%$ of the variance in juvenile and adult growth rates are explained by them. Table 6 shows the model predictions for instantaneous specific growth rates of Centropages typicus, Clausocalanus lividus and Temora stylifera. Although caution should be used concerning the prediction accuracy of these models, which can be of roughly an order of magnitude (Hirst \& Lampitt 1998), the growth rates found in our study (Table 3) were overall much lower than the predictions from both models (Table 6). This comparison suggests that during our study copepod egg production was strongly limited, very likely by food availability. This conclusion is also consistent with the results from our enrichment experiments. Unfortunately, the models of Hirst \& Lampitt (1998) did not take account of any independent variable related to food availability, which would have allowed further analysis and a comparison between oligotrophic and non-oligotrophic systems

Total (GF/F) chlorophyll did not appear to be a good estimator of food availability. As most copepods feed inefficiently on particles smaller than $5 \mu \mathrm{m}$ (Berggreen et al. 1988), when both total and $>5 \mu \mathrm{m}$ chlorophyll follow different distribution patterns (in time or space), total chlorophyll becomes a poor estimator of food availability for copepods (Dam \& Peterson 1991). The concentration of $>5 \mu \mathrm{m}$ chlorophyll seemed to be one of the main factors controlling egg production rates in our study. Thus, the decrease in egg production rates

Table 6. Instantaneous specific growth rates $\left(g, \mathrm{~d}^{-1}\right)$ predicted from global models of copepod growth rates for average Centropages typicus $(5.0 \mu \mathrm{g} \mathrm{C})$, Clausocalanus lividus $(8.7 \mu \mathrm{g} \mathrm{C})$ and Temora stylifera $\left(11.6 \mathrm{\mu g} \mathrm{C}\right.$ at $20^{\circ} \mathrm{C}$. Models 1 and 2 are from Hirst \& Lampitt (1998) for in situ copepod growth rates. Model 1 is for adult female of broadcast-spawning copepods; it is body-weight dependent and temperature independent. Model 2 is for juvenile broadcast-spawning copepods; the model is body-weight and temperature dependent. Model 3 is from Kiorboe \& Sabatini (1995) for maximal growth rates of broadcast-spawning copepods at $15^{\circ} \mathrm{C}$ is thodel is only body-weight dependent. Predictions of model 3 have been converted into rates at $20^{\circ} \mathrm{C}$ using $Q_{10}$ values of 3 (as in the original paper) and 4 .

\begin{tabular}{lcccc}
\hline Species & Model 1 & Model 2 & Model 3 & Model 3 \\
& & & $Q_{10}=3$ & $Q_{10}=4$ \\
\hline Centropages typicus & 0.09 & 0.24 & 0.33 & 0.37 \\
Clausocalanus lividus & 0.07 & 0.20 & 0.29 & 0.33 \\
Temora stylifera & 0.06 & 0.18 & 0.27 & 0.31 \\
\hline
\end{tabular}


of Centropages typicus and Clausocalanus lividus along the transect paralleled the decrease in $>5 \mu \mathrm{m}$ chlorophyll concentration. The lower egg production rates observed in oceanic waters were consistent with the fact that those copepods required a longer time to achieve higher egg production rates after food enrichment. Both facts suggest that the copepods from the open sea were in worse condition regarding food availability.

In spite of this decrease in ensemble average egg production rates coinciding with the changes in $>5 \mu \mathrm{m}$ chlorophyll through the transect, the statistical relationship between egg production rates and $>5 \mu \mathrm{m}$ chlorophyll concentration was weak or absent when considering all of the individual data together (instead of the ensemble averages). This lack of a significant relationship in the regression analysis was probably due to the scatter in the data and also to the small range of chlorophyll values found during the study (total chlorophyll: depth-weighted averages from 0.29 to $0.66 \mathrm{\mu g} \mathrm{l}^{-1}$; $>5 \mu \mathrm{m}$ chlorophyll: from 0.09 to

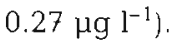

We cannot disregard the possibility, however, that other non-pigmented potential food items might follow a similar inshore-offshore gradient and be partially responsible for the egg production observed. Assuming a gross growth efficiency of $40 \%$ (Kiørboe et al. 1985) and a phytoplankton carbon:chlorophyll ratio (C:chl) for the northwestern Mediterranean (Delgado et al. 1992, Arin pers. comm.) between 10 (which would be close to values for the deep chlorophyll maximum) and 40 (which would be close to surface values), and given the availability of pigmented food items (based on chlorophyll $>5 \mu \mathrm{m}$ ), it appears that chlorophyll concentration is not always sufficient to explain the observed egg production rates (Table 5). The unrealistic clearance rates on pigmented items required, particularly for Centropages typicus in shelf and shelfbreak waters, suggest an important contribution of microzooplanklon to the copepod diet in order to fulfill the carbon requirements for egg production.

In the case of Temora stylifera, the lack of such a trend in egg production rates from coastal to open sea waters is not clear. It might be a consequence of a restricted data set, due to the limited number of visits where adult females were found. The scarcity of this species during the cruise is related to its seasonal pattern of abundance in the western Mediterranean (Mazzocchi \& Ribera d'Alcalà 1995).

The Catalan Front, associated with the shelfbreak, has been suggested to be an area of higher production within the relative oligotrophy of the Mediterranean (Estrada 1996, and Boucher et al. 1987 for the Ligurian Sea Front). Previous studies in this area have shown that some groups of zooplankton tend to concentrate in the vicinity of the hydrographic front, while their distribution was more heterogeneous in coastal waters (Boucher 1984, Sabatés et al. 1989, Saiz et al. 1992, Sabatés \& Olivar 1996). Our data showed that mesozooplankton and copepod abundance (integrated for the water column) in shelfbreak waters was similar to shelf and oceanic waters. This discrepancy might be a consequence of a non-optimal design of our sampling for the study of frontal processes, because we had a station located geographically at the shelfbreak, whereas the position of the front might change. It is also possible that in summer and during other periods when stratification overrides the density front at the surface, the effects of the front might be smaller.

One interesting aspect of these results on egg production and copepod distribution is that, in spite of higher egg production rates in shelf and shelfbreak waters, copepod abundance was not significantly higher in those waters compared to the oceanic stations. During the same cruise, the distribution of microzooplanktonic copepods $(>53 \mu \mathrm{m})$ showed a similar pattern to that of mesozooplankton, with no significant differences between stations (Sabatés pers. comm.). This uncoupling between egg production (growth rates) and abundance (biomass) suggests that mortality and/or export of populations must be higher in these waters than in the open sea. Available data for predation rates on copepods by fish larvae (Sabatés pers. comm.) and chaetognaths (Duró \& Saiz in press). however, suggest that predation pressure by these organisms at the time of the study was higher in oceanic waters. We have no information on other potential predators.

Our $Q_{10}$ value for egg production of Centropages typicus was higher than values reported for juvenile development and growth of copepods (see Kiørboe \& Sabatini 1995), as well as the value of 2.9 for egg production of Calanus glacialis (Hirche \& Bohrer 1987); however, it was similar to the value found for another small neritic copepod (Acartia grani, $Q_{10}=4.4$, Saiz et al. 1998). These high values suggest both life-strategy specific and among-physiological process differences in the response to changes in temperature. However, the scarcity of copepod data on $Q_{10}$ values for egg production and other metabolic processes precludes any further discussion.

Finally, our observation of natural mortality associated with significant egg production is remarkable. Two interesting facts arise from this observation:

(1) In spite of being senescent and dying within the same day, the females were still laying eggs. This fact indicates that the post-reproductive period of the females (sensu Ohman et al. 1996) was practically nonexistent for this species. Carlotti et al. (1997) also reported that for Centropages typicus '...some females 
still produced a large number of eggs the day before their death'. According to Ohman et al. (1996), mortality rates play a very important role in modulating the fecundity of copepods due to changes in the demographic composition of adult females (from females in the pre-reproductive period to females in the reproductive and post-reproductive periods). A very short or absent post-reproductive period would imply no effect of reasonably low mortality rates on fecundity. If this were the case, fecundity would be expected to be driven mainly by temperature and/or food availability. This prediction agrees with the observed relation between egg production rates (fecundity) and availability of $>5 \mu \mathrm{m}$ chlorophyll, given the small differences in temperature between stations.

(2) The eggs laid by senescent females were most likely viable. We did not conduct any test on the hatching success of these eggs, but they were mainly of the spiny form, which seems to be the normal and viable form of eggs of Centropages typicus (Carlotti et al. 1997).

In this study, we have shown that copepod egg production in the western Mediterranean in late springearly summer is strongly limited and linked to the concentration of $>5 \mu \mathrm{m}$ chlorophyll. However, the amount of pigmented food items is not sufficient to explain the recorded egg production rates, and other non-pigmented items must be important components of the copepod diet. The patterns in copepod production observed do not seem sufficient to explain the distribution of copepods from coastal to oceanic waters. Other factors, such as advection and predation pressure, should be taken into account in explaining the distribution pattern.

Acknowledgements. The authors are indebted to Cèlia Marrasé, Elisa Berdalet and Laura Arin, who conducted part of the pigment analysis, and to the rest of the participants in cruises VARIMED-95 and FRONTS-95 for their occasional assistance. We also thank the anonymous referees for their helpful comments. Financial support was provided by projects AMB94-0853, AMB94-1019, MAS2-CT93-0063 and MAS3-CT96-0051

\section{LITERATURE CITED}

Alcaraz M (1985) Vertical distribution of zooplankton biomass during summer stratification in the Western Mediterranean. In: Gibbs PE (ed) Proc 19th Eur Mar Biol. Symp. Cambridge Univ Press, Cambridge, p 135-143

Ban S (1994) Effect of temperature and food concentration on post-embryonic development, egg production and adult body size of calanoid copepod Eurytemora affinis. J Plankton Res 16:721-735

Berggreen U, Hansen B, Kiørboe T (1988) Food size spectra, ingestion and growth of the copepod Acartia tonsa during development: implications for determination of copepod production. Mar Biol 99:341-352

Boucher $J$ (1984) Localization of zooplankton populations in the Ligurian marine front: role of ontogenic migration. Deep-Sea Res 29:953-965

Boucher J, Ibañez FI, Prieur L (1987) Daily and seasonal variations in the spatial distribution of zooplankton populations in relation to the physical structure in the Ligurian Sea Front. J Mar Res 45:133-173

Calbet A, Alcaraz M, Saiz E, Estrada M, Trepat I (1996) Planktonic herbivorous food webs in the Catalan Sea (NW Mediterranean): temporal variability and comparison of indices of phyto-zooplankton coupling based on state variables and rate processes. J Plankton Res 18:2329-2347

Carlotti F, Rey C, Javanshir A, Nival S (1997) Laboratory studies on egg and faecal pellet production of Centropages typicus: effect of age, effect of temperature, individual variability. J Plankton Res 19:1143-1165

Chisholm LA, Roff JC (1990a) Abundances, growth rates, and production of tropical neritic copepods off Kingston, Jamaica. Mar Biol 106:79-89

Chisholm LA, Roff JC (1990b) Size-weight relationships and biomass of tropical neritic copepods off Kingston, Jamaica. Mar Biol 106:71-77

Dam HG, Peterson WT (1991) In situ feeding behavior of the copepod Temora longicornis: effects of seasonal changes in chlorophyll size fractions and female size. Mar Ecol Prog Ser 71:113-123

Davis CS, Alatalo P (1992) Effects of constant and intermittent food supply on life-history parameters in a marine copepod. Limnol Oceanogr 37:1618-1639

Duró A, Saiz E (in press) Distribution and trophic ecology of chaetognaths in the Western Mediterranean in relation to an inshore-offshore gradient. J Plankton Res

Delgado M. Latasa M. Estrada M (1992) Variability in the size-fractionated distribution of the phytoplankton across the Catalan front of the north-west Mediterranean. J Plankton Res 14:753-771

Estrada M (1996) Primary production in the northwestern Mediterranean. Sci Mar 60(Suppl 2):55-64

Hay S (1995) Egg production and secondary production of common North Sea copepods: field estimates with regional and seasonal comparisons. ICES J Mar Sci 52: 315-327

Hirche HJ, Bohrer RN (1987) Reproduction of the Arctic copepod Calanus glacialis in Fram Strait. Mar Biol 94:11-17

Hirst AG, Lampitt RS (1998) Towards a global model of in situ weight-specific growth in marine planktonic copepods Mar Biol 132:247-257

Hirst AG, Sheader M (1997) Are in situ weight-specific growth rates body-size independent in marine planktonic copepods? A re-analysis of the global syntheses and a new empirical model. Mar Ecol Prog Ser 154:155-165

Hopcroft RR, Roff JC (1998) Zooplankton growth rates: the influence of female size and resources on egg production of tropical marine copepods. Mar Biol 132:79-86

Huntley ME, López MDG (1992) Temperature-dependent production of marine copepods: a global synthesis. Am Nat 140:201-242

Ianora A, Buttino I (1990) Seasonal cycles in population abundances and egg production rates in the planktonic copepods Centropages typicus and Acartia clausi. J Plankton Res 12:473-481

Jónasdóttir SH, Fields D. Pantoja S (1995) Copepod egg production in Long Island Sound, USA, as a function of the chemical composition of seston. Mar Ecol Prog Ser 119: $87-98$

Kimmerer WJ, McKinnon AD (1989) Zooplankton in a marine 
bay. III. Evidence for influence of vertebrate predation on distributions of two common copepods. Mar Ecol Prog Ser 53:21-35

Kiorboe T, Nielsen TG (1994) Regulation of zooplankton biomass and production in a temperate, coastal ecosystem. 1 Copepods. Limnol Oceanogr 39:493-507

Kiorboe T, Sabatini M (1995) Scaling of fecundity, growth and development in marine planktonic copepods. Mar Ecol Prog Ser 120:285-298

Kiørboe T, Møhlenberg F, Hamburger K (1985) Bioenergetics of the planktonic copepod Acartia tonsa: relation between feeding, egg production and respiration, and composition of specific dynamic action. Mar Ecol Prog Ser 26:85-97

Mazzocchi MG, Ribera d'Alcalà M (1995) Recurrent patterns in zooplankton structure and succession in a variable coastal environment. ICES J Mar Sci 52:679-691

Ohman MD, Aksnes DL, Runge JA (1996) The interrelationship of copepod fecundity and mortality. Limnol Oceanogr 41:1470-1477

Owen RW (1989) Microscale and finescale variations of small plankton in coastal and pelagic environments. J Mar Res 47:197-240

Parsons TR, Takahasi M, Hargrave B (1984) Biological oceanographic processes. Pergamon Press, New York

Peterson WT, Kimmerer WJ (1994) Processes controlling recruitment of the marine calanoid copepod Temora longicornis in Long Island Sound: egg production, egg mortality, and cohort survival rates. Limnol Oceanogr 39: $1594-1605$

Peterson WT, Tiselius P, Kiørboe T (1991) Copepod egg production, moulting and growth rates, and secondary production, in the Skagerrak in August 1988. J Plankton Res 13:131-154

Plourde S, Runge JA (1993) Reproduction of the planktonic copepod Calanus finmarchicus in the Lower St. Lawrence estuary: relation to the cycle of phytoplankton production and evidence for a Calanus pump. Mar Ecol Prog Ser 102: $217-227$

Editorial responsibility: Otto Kinne (Editor),

Oldendorf/Luhe, Germany
Sabatés A, Olivar P (1996) Variation of larval fish distributions associated with variability in the location of a shelf-slope front. Mar Ecol Prog Ser 135:11-20

Sabatés A, Gili JM, Pagès F (1989) Relationship between zooplankton distribution, geographic characteristics and hydrographic patterns off the Catalan coast (western Mediterranean). Mar Biol 103:153-159

Saiz E, Calbet A (1999) On the free-spawning reproductive behaviour of the copepod Clausocalanus lividus (Frost and Fleminger 1968). J Plankton Res 21:599-602

Saiz E, Rodríquez V, Alcaraz M (1992) Spatial distribution and feeding rates of Centropages typicus in relation to frontal hydrographic structures in the Catalan Sea (western Mediterranean). Mar Biol 112:49-56

Saiz E, Calbet A, Fara A, Berdalet E (1998) RNA content of copepods as a tool for determining adult growth rates in the field. Limnol Oceanogr 43:465-470

Salat J (1996) Review of hydrographic environmental factors that may influence anchovy habitats in northwestern Mediterranean. Sci Mar 60(Suppl 2):21-32

Sazhina LI (1985) Fecundity and growth rate of copepods in different dynamic zones of equatorial countercurrent of the Indian Ocean. Pol Arch Hydrobiol 32:491-505

Sekiguchi H, McLaren IA, Corkett CJ (1980) Relationship between growth rate and egg production in the copepod Acartia clausi hudsonica. Mar Biol 58:133-138

Smith SL, Lane PVZ (1985) Laboratory studies of the marine copepod Centropages typicus: egg production and development rates. Mar Biol 85:153-162

Smith SL, Lane PVZ (1987) On the life history of Centropages typicus: responses to a fall diatom bloom in the New York Bight. Mar Biol 95:305-313

Tiselius P, Nielsen TG, Breuel G, Jaanus A, Korshenko A, Witek $Z$ (1991) Copepod egg production in the Skagerrak during SKAGEX, May-June 1990. Mar Biol 111:445-453

Webber MK, Roff JC (1995) Annual biomass and production of the oceanic copepod community off Discovery Bay, Jamaica. Mar Biol 123:481-495

Submitted: December 22, 1998; Accepted: May 5, 1999

Proofs received from author(s): October 1, 1999 